\title{
MACABRE DIMENSIONS OF CRIMES AND INSECURITY IN NIGERIA AND THE IMPERATIVES OF COMMUNITY POLICING
}

\section{Dr. Oluwasolape Onafowora ${ }^{1}$, Dr. Temitope Francis Abiodun ${ }^{2}$, Dr. Olanrewaju Lateef Yusuf ${ }^{2}$ and Marcus Temitayo Akinlade ${ }^{3}$}

${ }^{1}$ Department of History and International Relations, Federal University Oye-Ekiti, Nigeria

${ }^{2}$ Department of Peace, Security and Humanitarian Studies, Faculty of Multidisciplinary Studies University of Ibadan, Ibadan, Nigeria

${ }^{3}$ Department of Political Science and International Diplomacy, School of Social and Management Sciences, Bamidele Olumilua University of Education, Science and

Technology, Ikere-Ekiti, Ekiti State, Nigeria

Cite this article:

Oluwasolape O., Temitope F.A., Olanrewaju L.Y., Marcus T.A. (2021), Macabre Dimensions of Crimes and Insecurity in Nigeria and the Imperatives of Community Policing. African Journal of Social Sciences and Humanities Research 4(2), 5973. DOI: $10.52589 / A J S S H R-$ 7CRBAFWW.

\section{Manuscript History}

Received: 22 March 2021

Accepted: 17 April 2021

Published: 27 April 2021

Copyright $\odot 2020$ The Author(s). This is an Open Access article distributed under the terms of Creative Commons AttributionNonCommercialNoDerivatives 4.0 International (CC BY-NC-ND 4.0 ), which permits anyone to share, use, reproduce and redistribute in any medium, provided the original author and source are credited.
ABSTRACT: The paper focuses on community policing, a recent concept taken to as additive to law enforcement which has become everyone's allegorical remedy for policing problems in the global system. The concept as an agenda for policing reform, has received numerous attentions, having received scholarly debates in various. In Sub-Saharan African region, and most especially Nigerian state where issues of crimes and insecurity have taken different dimensions, there have been agitations and a need to get an alternative to security structure in the country. Officers of the Nigeria Police are conspicuously overwhelmed in the discharge of their fundamental duties, there is, therefore, the need for community policing to complement their efforts in the maintenance of internal security and protection of lives and property. Therefore, this study interrogates the factors aiding the surge of crimes and ineffective policing in Nigeria, and also examines the merits derivable in subscription to the community policing viewpoint. The study gathered its data from secondary sources. The study in its findings, reveal that: a disconnect between the people and government, interagency rivalry, absence of intelligence gathering on the part of the security agencies, nonprosecution of violence perpetrators, amongst others, aid the surge of crimes and ineffective policing in the state. It as well argues that community policing would definitely go a long way in reversing the current state of insecurity for good in Nigeria. The paper, in its recommendations, submits that both the police and the public should jettison the rigid notion of rivalries between them, and should cultivate the force of togetherness and become partners in the course of securing lives and property in the society.

KEYWORDS: Community Policing, Crimes and Insecurity, Nigeria Police, Security, Nigeria 


\section{INTRODUCTION}

Crimes and insecurity remain on the increase in Nigeria in recent times notwithstanding the concerted efforts of various security agencies, most especially the Nigerian Police in ensuring peace and security of lives and property. The growing trend of insecurity is largely reflected in the daily incidents of kidnapping, armed robbery, human trafficking, assassination, terrorism and militancy in nearly all parts of the country (Osakwe, 2009). Insecurity without doubt is one of the major problems confronting Nigeria especially in the last one decade. This situation has become very worrisome considering the basic government's responsibility in the protection of lives and properties of Nigerians as reflected in the 1999 Constitution (Federal Republic of Nigerian Constitution, 1999). In 2009, Nigeria was listed among the 15 most vulnerable nations in the world (Ocholi, 2009). This position did not only corroborate the internal security situation, but also confirmed the increasing loss of competence by respective governments to perform basic security and developmental responsibilities despite repeated claims of huge budgetary allocation and government's expenditures on security (Ocholi, 2009).

However, policing has always remained imperative in all societies for the preservation of order, safety and social relations. The necessity of policing therefore becomes more evident in modern societies that are characterized by diversities and contradictions arising from population explosions, industrialization, urbanization, and conflicting ideologies on socio political and economic form of organization (Reiner, 2002). However, the emergence of the police, a body of men recruited and paid by the state to enforce law and maintain order remains a recent development in human history. Fundamentally, policing is supposed to be the responsibility of all grown-up adults in the society. That is the reason in medieval society, adult males were all obliged to contribute towards the prevention of crime and maintenance of order; this period preceded the emergence of specialized police forces as organs of the state (Weber, 1968). Therefore, birth of the state adorned with an avalanche of bureaucratic features: hierarchical power structure centralization, and professionalism, charge the traditional policing philosophy entrenched in the idea of policing as every man's assignment. In the same vein, the state emerging as an entity resulted into the creation of specialized agencies of the police and the armed forces for the maintenance of security.

That is the reason Abdulrahaman (2007) reveals that community policing is anchored on a systematic relationship between the police and the entire citizenry. Police roles are not simply law enforcement but include tackling a huge range of community problems (Tamuno, 1993). Indeed, community policing as a practice is a veritable vehicle for police reforms in the country. The Nigeria Police in 2004 embraced community policing as a pragmatic approach to police reforms in which the stage was indeed set for a clear departure from traditional policing, that was reactive and incident based, to a problem-solving oriented policing that is proactive with the community as the cornerstone of policing objectives (Abdularahman, 2007). Over six decades ago, scholars made some experimentation with community and neighbourhood-based policing projects but the assertions then, got mixed outcomes and these got abandoned because of soaring costs, citizen's apathy and administrative neglect respectively. However, higher crime rates and insecurity; and failure to control all these dimensions of insecurity once again gave impetus for the resurgence of the concept and idea of community policing in contemporary policing. This paper, therefore, interrogates the factors aiding the surge of crimes or insecurity and ineffective policing in Nigeria, and also examines the merits derivable in subscription to the community policing viewpoint. 


\section{CONCEPTUAL CLARIFICATION}

\section{Community Policing}

To have a clear comprehension of the concept of "community policing", there is need for readers to separately first have a clear-cut understanding of what is meant by a "community" itself and "policing" on the other hand. Community encompasses the neighbourhood in which people live; and it means a group of people with common identity, such as race, ethnicity or religion; and also, people with common profession, interest or needs (Wong, 2009). However, in Africa, communities may be formed on the basis of kinship and the extended family system while in primitive or traditional Africa, the family community is extremely important as the family was the basic component of social structure. In the same vein, numerous traditional African societies were interpreted on the principle of experience, lineage segmentation, unity, focusing on the political representation of a ruling family, and as well related through affinity to the clan of commoners (Shorter, 1977).

In addition, the concept of community according to Dambazau (2007) is defined in relation to the society, and a geographical area with definite legal boundaries, occupied by residents engaged in interrelated economic activities and constituting a politically self-governing unit. Therefore, policing refers to the activity of state police. However, policing is not ordinarily an activity of the state police, but it involves any organized activity that seeks to ensure the maintenance of order, security and peace through elements of prevention, deterrence, investigation of breaches, and punishment in a society (Baker, 2008). Therefore, it is a mechanism of governance and it could be authorized and provided by non-state actors or groups in a state. Definitions of community policing have abound as stipulated by scholars. In the same vein, Wrobleski and Hess argue (2003) that community policing remains an organization wide belief that usually enhances community, government and police partnerships; pro-active problem solving; and engagement to address the causes of insecurity, crime, fear and other community issues".

The imperative of community policing is to return to the day when safety and security are participatory in nature and everyone assumes responsibility for the general good and safety of the community but absolutely everyone living in the community (Brown, 2001). In the same vein, community policing is as well conceptualized to be collaborative effort between the police and the community that usually identifies problems of insecurity, crime and disorder and as well involves all elements of the community in the search for solutions to the identified problems. It attempts to actively involve the community with the police in the task of crime control by creating an effective working partnership between the community and the police. Under the community policing ideal, members in the community and the police are definitely expected to share some forms of responsibility in order to establish and maintain peaceful neighbourhoods.

\section{Components of Community Policing}

Components of community policing with reference to the Chicago alternative policing strategy as stated in the work of McEwen (1998:13) include: (a) the entire police department and the city are involved; (b) Police Officers are required to have permanent beat of assignments; (c) stern commitment to training activities; (d) the existing community plays essential role in the system; (e) Police institution is connected to the city services delivery; 
and (f) lastly an emphasis is laid on crime analysis. Furthermore, the key elements of community policing are universally recognized to include: problem solving, community affiliation, and change management. Therefore, the problem-solving aspect of it requires much energy and action than traditional incident based policing responses to crime and disorder. In maintaining a synergy, the police and members of the community and business owners usually identify core problems or the other, propose solutions, and implement a solution. Thus, community members identify the concerns that they feel are most threatening to their safety and well-being. Those areas concern then become priorities of joint policecommunity interventions (Bohn and Haley, 2002). The other component in the area of change management, police institution and officers are enjoined to be most familiar with the needs and concerns of their communities and should be in the best position to enhance safe relationship with the community, in other to give room for effective remedies to local security failures. However, police institution or management endeavours to come up with a way in regulating the local patrol officers' behaviour and action and must ensure that officers have the necessary resources in tackling the security impediments in the communities (Okiro, 2007).

\section{METHODOLOGY}

The qualitative research method of the social sciences was adopted; this method includes gathering data from the primary and secondary sources. The secondary sources include: relevant publications or books, texts, the internet, journals and other sources that form the body of scholarly works on the subject matter has been used in the study. Also the primary source avails the researchers the opportunity to gather data a Key Informant Interviews (KIIs) with some police chiefs and military personnel via Whatsapp calls and others. Also, the techniques for analyzing these secondary data are textual analysis and explanatory method. Textual analysis implies analyzing the content of books, journal articles, monographs, unpublished theses and internet materials while explanatory method implies interpretation of existing texts on a subject matter. Therefore, this entails drawing inferences, premises, conclusions and implications from a scholar's work. However, this explanatory method is relevant to the study of insecurity and community policing given the importance of interpretation to this work.

\section{THEORETICAL FRAMEWORK}

\section{Anomie Theory}

The Anomie Strain Theory is an offshoot of sociology and criminology theory developed that was developed in year 1938 by Robert Merton, espoused in his work titled "social structure and anomie." The theory argues that society puts pressures on individuals to attain socially accepted goals, whereas they usually lack the means. Therefore, this leads into strain which may later push individuals to commit crimes, mayhem on unleashing on the society, insurgency, drugs or cocaine pushing, joining terrorist groups or involving in all sorts of social vices. However, Robert Merton's theory emanates from a fundamental question posed for the American society on why the levels of deviance were so diverse among different societies (Brown, Esbensen and Geis, 2010). The theorist also argued there could be deviance 
where there is a disparity between what defines success and the proper means to attain designed goals. In the same vein, Merton argued that when individuals are confronted with a gap between their goals and their current status, strains usually become order of the day. It is argued that crime springs up from the divergence between the social objectives that are recognized as legitimate and the limited access to the means necessary to attain the objectives (Brown, Esbensen and Geis, 2010).

Moreover, the theory has effects on criminal policies, and it points to the much-quoted synergy between social and criminal policy. The theory is, therefore, majorly utilitarian in nature; and people resort to all sorts of acts of criminality as they lack alternative possibilities. And Merton explains that monetary crimes such as burglaries among others and due to the lack of access to legitimate means to achieve goals, and criminality only exists within the lower class as it is assumed that the middle and upper classes are endowed with these means at their disposal (Brown et al, 2010). This theory, therefore, assists us to comprehend the world view of criminals, armed robbers, kidnappers, terrorist groups, illicit drug carriers, and their interactions with and commitment of crimes and also implications of their atrocious activities to Nigerian security at large.

\section{Social Learning Theory}

The social learning theory is an offshoot of Sutherland's differential association theory to elucidate acts that violate social norms (Akers, 1998). And the basic assumption behind social learning theory is that the same learning process can produce both conforming and deviant or delinquent behavior in all sense. Akers (1998) posits that four (4) variables function to initiate and strengthen attitudes toward social behaviour; definitions, differential association, modeling and reinforcement. Therefore, balance of these influences determines if one will be prone to engage in deviant behaviour. The central variable in social learning theory is differential association with whom one associates frequently. In the same vein, Akers submits that individuals develop both favourable or unfavourable definitions to deviance in interactions with their peers.

Moreover, peers usually provide models of behaviour to follow; therefore, social learning theory has received considerable scholarly attention and empirical support in recent time. It is, however, tended to be on explaining crime and delinquency more generally, and not only police misconduct. According to Alpert and Dunham (1997), there is pressure on police and one of the most thoughtful pressures operating in police agencies is peer influence. In this vein, most researchers and police officers acknowledge the existence of a police subculture (Conser 1980). The subculture facilitates deviant behaviour by transmitting the beliefs, values, definitions, and manners of expression that deviate from acceptable behaviour; and this comes into play owing to the fact that the subculture shared value system gives them the opportunity to rationalize, excuse, and justify deviance (Kappeler et al. 1998).

There is avalanche of data on the extent of police misconduct, brutality, and corruption. By the way, there are no national level statistics on the extent of police deviance; it may be due to the fact that almost every police department has witnessed one form of police corruption or the other Kappeler et al., 1998; McCafferty, Souryal, and McCafferty, 1998). Policing is adjudged to be a unique profession with various characteristics that contribute to the opportunity for deviant behavior (Barker 1977). In the same vein, police officers usually enjoy freedoms that are not usually accorded to regular citizens; speeding, using deadly force, 
seizing property, among others. At the same time, not only does the career provide many opportunities for deviance, but it also provides justifications if the behaviour is questioned. Moreover, deviant officers are unlikely to be detected because of loose supervision and the fact that officers often work in isolation from public observation. Police misconduct has, however, been conceptualized in many ways and this has been meant to describe many different actions, including drug using and selling, brutality, protection of illegal activity, insubordination, and neglect of duty. This study focuses on taking or accepting gifts and meals from the general public, opportunistic theft, and as well the use of excessive force.

According to Alpert and Dunham (1997), acceptance of meals and gifts is one of the most common and most extensive forms of police corruption in the society. Many cities actually allow officers to accept free or discount meals. It is often not accepted behaviour when it is an act of appreciation toward the police, but sometimes the motive is to buy protection from the police. In other words, some businesses offer free items or services in expectation for quicker response times and extra protection from the police. Alpert and Dunham (1997) describe "opportunistic theft" as a result of situations that provide unusual opportunities for theft. For example, the police are likely the first respondents to a burglary call. Meanwhile as soon as the belongings have already been taken illegally in a society, the opportunity presents itself to steal and blame it on the burglary. Another instance is by accepting money or drugs from drug dealers and failing to report it to the police department. This theory, therefore, helps us to understand the world view of how police officers in Nigeria have soiled themselves as a result of corruption, indulgence in crimes and gross misconduct in all ramifications, thereby rendering the agency impotent and incompetent in manning the security and maintaining law and order in the country.

\section{OVERVIEW OF THE NIGERIA POLICE COMPETENCE IN MANAGING THE INTERNAL SECURITY IN NIGERIA}

Nigerians are, no doubt, now skeptical about the capability of the Nigeria Police in curbing the spate of insecurity in the country. The credence is that the police have not the wherewithal to adequately and effectively control and curtail all sorts of crime and criminality in the state. However, the current Nigeria Police has now been taken by citizenry to mean the contrary to statutory police whose primary assignment is to maintain law and order in the society (Adekunle, 2013). In the real sense, police is known to be a civil force to which is entrusted the task of maintaining public order and enforcement of law for the prevention and punishment of its breaches (Alderson, 1883). Taking a cursory look at the definitions above, it obvious that the term, police, means nothing short of law enforcement and regulations; maintenance of public order with a view to preventing crimes and at the same time punishing those who breach the laws. Having been duly informed of what police responsibilities entail, there should not be any reason to doubt the competence of Nigeria Police; and if that is the case, what wrong with it?

Actually, Nigeria Police is bedeviled with myriads of difficulties. In the first instance, the problem emanates rightly from the recruitment process and the quality of people recruited into the system remains the major $\operatorname{cog}$ in the wheel. This assertion is very pertinent among 
the lowly-ranked officers who remain poorly educated, ill-trained, thereby presenting the Nigeria Police in bad light (Adekunle, 2013). Also, the Nigeria Police lacks discipline and professionalism; and another problem bedeviling the Force is corruption which remains the general public belief. This is evident in the way the police officers are seen on the roads on daily basis begging for alms and taking bribes from motorists among others in the society.

Another problem affecting the effectiveness of the Nigeria Police is the fact that they are provided with old or obsolete weapons or ammunitions in the fight of crime in the country. This is contrary to the situation whereby the criminals being fought in the society go out with and brandish modern or sophisticated weapons like AK-47, Kalanikov, RPG, among others (Abiodun, 2018). Also added to this is the unavailability of arms for crime detection, control, prevention and investigation; and even the scientific technique of investigation which remains a critical tool of modern policing is totally lacking in all ramifications. In another way, the Nigerian government has failed woefully to increase the budgetary allocations of security agencies for years and even if increased, the level of implementation is usually at low ebb, thereby damping the morale of the officers (Abiodun, Asaolu and Ndubuisi, 2020).

Also bedeviled by the numerous challenges, officers of the Nigeria Police usually find it very difficult to respond to distress calls from the public as expected while in trouble. This has, however, given the Nigeria Police a poor public image; and that is one of the major reasons Nigerians are not even willing or ready to join or assist them in crime detection and control in the society. There was even a bad scenario during the recent \#EndSARS\# protest in Nigeria, nearly all the citizenry came down heavily on the officers, and this led to death of a large number in the Nigeria Police Force (Abiodun, Asaolu and Ndubuisi, 2020).

Primarily, police institutions are organized to defend and preserve the interests of groups and classes in society. Consequently, the significance of police as either facilitators or inhibitors of change initiatives depends on the nature of the society. In a totalitarian and economically inequitable society, police role will be more to defend the status quo of political oppression and economic injustice (Tamuno, 1993) while in a saner or democratic society, the police are much more expected to provide services that will enhance development and democracy. The Nigeria Police's duty is to provide security would be consistently acknowledged even during emergencies but opposite is becoming the case as there are cases and instances of: kidnapping for rituals and ransom, terrorism and banditry, armed robbery among others. These are occasioned by the limiting factors that include; lack of resources, poor condition of service for staff poor government support, resulting in ill-motivated, ill-equipped and insufficient workforce in the country (Rotimi, 2001).

Presently, the trend of insecurity in Nigeria involving crimes of; armed banditry, terrorism, kidnapping, armed robbery, among others, are on the increase constitute a sort of worry to major stakeholders and the public at large. The trend has taken several dimensions and it is becoming more dreadful owing to the fact that the Nigeria Police is incapacitated and lacks ability to effectively control arrest the situation pursuant to some inherent challenges in the system. Actually, the role of the Nigeria Police on security matters has been rated very poor as a result of its deprived correlation with local community it purports to serve (Tamuno, 1993). Arising from these failures in all ramifications, nearly all Nigerian communities have resorted to self-help with the inauguration or setting up of local, state, and regional vigilante security outfits to complement the police efforts. Therefore, most of these local security outfits or Vigilante groups have assumed the role of security managers in different 
communities. Numbers of security outfits have risen up to provide semi-equipped and trained personnel for the post of security officers in various establishments or public places; churches, schools, residential apartments, banks, market places to prevent vandalism and theft. Even more facts have emerged that there are some remote villages in Nigeria that lack access to security or police presence, hence the need to embrace community policing.

\section{HIGHLIGHTS OF SOME OF THE CONTEMPORARY SECURITY THREATS IN NIGERIA}

Numerous literature materials exist that chronicle elaborate case studies of insecurity in the country from different informed prisms. This study does not attempt to duplicate efforts but singles out the selected cases of insecurity in the country; and these security challenges have been briefly highlighted as follows:

\section{Cattle Rustling and Armed Banditry}

These acts of cattle rustling and armed banditry are interwoven in most pastoral communities of Nigeria and sub-Saharan Africa; and only on few instances, rustling could take place without even involving any banditry. This fact does not wholly dispute the fact that there have been occasions where cattle were stolen in the night and even in the broad day light. In actual sense, East African region is believed to have high rate of cattle rustling in the continent of Africa. That is the reason the protocol of Eastern African Police Chiefs Cooperation (2008) legally defined cattle rustling as the stealing or planning, organizing attempting, aiding the poaching or stealing of livestock by anyone from one community to another, where the theft is accompanied by dangerous weapons and violence. By the way, there exist numerous factors that may have influenced the predominance of cross-border cattle rustling in West African region and they include among other; the inability of most states to govern effectively their hinterlands, borderlands, and forestlands (Ayuba, 2019).

\section{High Rate of Kidnappings in Nigeria}

The history of kidnapping in Nigeria has actually remained traceable to hostilities, conflicts and violence in the Niger Delta region (Abiodun e tal, 2019). And the problem of kidnapping which refers to the act of abducting someone and keeping him/her as a prisoner in order to get a ransom for his/her release, assumed a new dimension with a whole new economic attraction in nearly all parts of the country. However, the phenomenon has been successfully thriving in the South-South, South-West, South- East, North-West and other regions in Nigeria at present where prominent figures and even the poor in the states become easy targets. The kidnapped victims pay between the ranges between $\mathrm{N} 1 \mathrm{~m}$ to $\mathrm{N} 25 \mathrm{~m}$ as ransom in Nigeria to secure their release. Therefore, this criminal act has now become an easy way of making money (Abiodun e tal., 2019).

\section{Boko Haram Attacks in the Northeastern region of Nigeria}

This menace started in 2009 and still ravages the northeastern region till date; and has actually been the major security threat bedeviling the Nigerian state and has negatively affected the nation's socio-political, economy and human security in all ramifications. However, and as stated by Abiodun (2016), the word Boko Haram simply means "western 
education if forbidden or evil." The Boko Haram insurgency has remained a controversial Nigerian militant Islamic group that has tried to impose a Sharia Law or its own radical interpretation of Islam on northern Nigeria and as well then on other parts of the country. It is therefore affirmed that the group opposes not only western education, but also Western culture and modern science and over 1.9 million lives have been claimed and uncountable number of properties looted and destroyed (Adesola, 2021).

\section{Herders-Farmers Conflicts}

There is high rate of killings going on in Nigeria occasioned by the farmer-herders' conflict in the country. It is general fact that Nigeria at present remains very unsafe. Though this study does not intend to report the disgusting cruel butcher of over 73 human lives claimed in Benue State in recent time arising from the farmers-herdsmen crisis but it is necessary to simply buttress the level of insecurity that has bedevilled the land (Abiodun, 2020).

\section{Escalation of Ethno-Religious Conflicts}

In the same vein, ethno-religious conflicts have been identified as another instance of insecurity in Nigeria (Abiodun, 2020). And this ethno-religious conflict comes into play when the social relations between members of one ethnic or religious group and another of such group in a multi-ethnic and multi-religious society is typified by fear, mutual suspicion, lack of cordiality, and a tendency towards violent confrontations to settle grievances. These conflicts have also revolved around who gets what and how in the state especially as it concerns the distribution of scarce chieftaincy titles, resources, land, power, local government councils, control of markets and expansion of religious territories respectively (Abiodun, 2020).

\section{THE FACTORS AIDING INCREASE IN CRIMES RATES AND INSECURITY IN NIGERIA}

Based on the research conducted by Abiodun (2020), the growing rate of insecurity in Nigeria is as a result of the following factors or circumstances illustrated as follows:

\section{Rivalries among the various security agencies in Nigeria}

The failure of the security agencies such as; the police, the military, state security services and paramilitary units to collaborate and share intelligence information together or among themselves has been identified as one of the factors negating the quick apprehension of culprits.

\section{There is always a total disconnect between the ruler (government) and the ruled (citizenry)}

For long, there has been a mounting disconnect between the people and government. In the same parlance, the security agencies, whether military or civilian, have not tried to bridge this chasm, thus creating misunderstanding, mistrust and resentment. 


\section{Weak and Poorly Funded Military Establishments}

In addition to the high security vote which state governments in Nigeria receive on a monthly basis; there is growing spate of insecurity in many states. Some of these monies find their way into the pockets of some highly-placed private citizens and the Chief Executives of the states, leaving the hapless citizens to the mercy of criminals and sociopaths. Also, the armed forces, paramilitary establishments and the police under federal control are weak institutionally, heavily politicized and poorly funded. This status quo makes it easy for the nation's security to be compromised (Abiodun, 2020).

\section{Absence of intelligence gathering on the part of the security agencies}

Also, there is also failure of intelligence gathering on the part of security agencies, compliance of security operatives with proactive policing mechanism in the country, coupled with the non-apprehension and also prosecution of arrested culprits, is also a contributory factor to the rising tide of insecurity in Nigeria.

\section{Anger occasioned by perpetual non-prosecution of the identified perpetrators of violence in the country}

The lack of arrest and prosecution of perpetrators and sponsors of violence according to Abiodun (2020) has encouraged many more social deviants and their godfathers to throw caution to the wind to perpetrate evil in the land; and they usually go scot-free. The Nigerian society has become a rigout of powerful fiefdoms controlled by feudal lords who are almost as powerful as the state and maintain a rental economy within the larger national economy.

\section{Total erosion of socio-cultural and national or communal value system}

There is presently a total erosion of moral values in the country as one of the critical factors serving as pushes to the incessant security challenges in Nigeria. There is total collapse of communal value system which is supposed to position high quality and standards on human lives; all these are already completely depleted in the state (Abiodun, 2020).

\section{IMPERATIVES FOR COMMUNITY POLICING IN STEMMING THE TIDES OF INSECURITY IN NIGERIA}

As espoused in the argument of Okiro (2007), community policing now remains a paradigm shift that seeks to focus on constructive engagement with people who are seen to be the endusers of police service and as well re-negotiate the agreement between the citizenry and the police institution, thereby making the community members the partners of justice and standard police service. This submission was part of the Nigeria's Police duties by translating policing to a modern system that is very capable of providing maximum security of lives and property in a state. Moreover, community policing remains a pro-active idea that adequately simplifies problems that are seen to be criminal in nature or raises the spate of crimes in a society, having identified, analyzed and taken action on community woes (Sola, 2021).

Fundamentally, community policing remains a viewpoint with operating principles based on the assumption that changes at present will definitely make an impact and make communities to be safer and more inhabitable in the future; and this can only be attained by working 
together towards the communal goals (Sola, 2021). Community policing, therefore, brings the police and community closer and offers a number of other paybacks to the system. That is the major reason Sola (2021) elucidates the gains of community policing that should collaboration and attainment of security goals via community participation results into a diminish of crime rates and leads to higher arrest rates of criminals, the Police would definitely be the one to take the credit for being the foresighted agents of change in the state. And if on the other hand the community policing fails to improve public security as expected, there is still likelihood that the public would reduce support for policing as a swift plan another strategy may not necessarily work out (Adesola, 2021). Therefore, community policing reduces fear of crime and, from the viewpoint of political paybacks to police, delivers the message that police care and are alive to their responsibilities (Adesola, 2021).

However, Coquilhat (2008) agrees that the banes of community policing are to: (i) improve police-community synergy and community perceptions of police; (ii) increase community capacity to deal with issues affecting it; (iii) transform police officers' attitudes and behaviours; (iv) increase perceptions of safety; and at the same time to (v) reduce crime, disorder and anti-social behavior respectively.

\section{Improving police-community synergy and community perceptions of police}

Community policing enables police to develop improved police-community rapport; and this avails the police of the opportunity to meet the community's desires, while growing public accountability over police through participation. A number of ideas have actually shown positive improvements in police-community relations and community perceptions of the system.

\section{Increasing community capacity to deal with issues affecting it}

It has been affirmed that building community capacity has adequately mobilizes and empowered the communities to identify and respond to their much-coveted desires. The advantage of an empowered community is a stronger one that would participate in addressing issues affecting it. Therefore, community policing offers the public a larger window into police engagements and provides opportunities for support for the institution from the grass root.

\section{Transforming police officers' attitudes and behaviours for good in compliance with global best practices}

It is evident that community policing has positive effects on the police institution in all sense with increased job satisfaction and improved interaction with, and confidence in, the community it is meant to protect or serve. In Mayhill (2006) argument, it was revealed that community policing gives room for officers within the community where they serve to have more understanding of the local system and which has in the long run, promoted a positive image of police itself.

\section{Increasing perceptions of safety and as well allaying the fear of crimes}

Meanwhile, Skogan (2006) has argued that there is substantiation to the fact that increasing community-police interactions are connected with lower levels in fear of crime. However, police and the community have contradictory intensities of perceptions concerning security 
and this has always been suggested that police are more likely to perceive a reduction in the fear of crime than the community being protected.

\section{Reducing crime, disorder and anti-social behaviour}

Community policing has remained positive as a policing approach to address the dimensions of insecurity, crime, disorder and anti-social behaviours in a state or society. The approach has been tested and deployed in the various Western states to address attacks on lives and property damage emanating from gang violence and organized crime (Skogan, 2006). Also in recent times, the adoption of the Civilian Joint Task Force in the northern parts of Nigeria has greatly helped in easy identification and fight against terrorist activities in some communities in Yobe, Borno, Bauchi, Adamawa and others (Donli, 2021).

\section{Limitations to the Study}

The nature of this study and the study area posed a great constraint to it on account of sensitivity of the data that were sought and as well the perceived security implications. The point that the study involved a process that was still ongoing, therefore, the means and process of gathering data involved dynamic stages, thereby posing some challenges. In addition, the need to interview the Nigeria Police officers who their morale was still down or at a very low ebb after the turbulent turmoil they encountered after the recent \#EndSARS\# protests in Nigeria also affected the researchers' security and chances of getting more data for the study.

\section{Acknowledgement}

The researchers appreciate the input of the various selected respondents for their efforts during the work.

\section{CONCLUSION}

The Nigeria Police is seen to be fraught with avalanche of problems and they engage in numerous activities which make the public lose confidence in the system and the general public are seemed to have even distanced themselves from the police in all ramifications. Presently, the Nigerians no longer view or police as their protector or law enforcer as far as lives and properties are concerned but rather as extortionists. These therefore require certain consideration or measure to be taken in order to strengthen the relation between the police and the public. And there is urgent need for more strengthened synergy between the police and the public in a bid to facilitate and enhance police competence and ability at crime prevention and control. This is required since the citizenry or general public usually provide most of the information about crime; otherwise, most of the crimes committed will go unidentified. 


\section{RECOMMENDATIONS}

Based on the above, this paper therefore recommends the following for policy formulation to ensure effective and workable police-community relations and community policing in Nigeria:

(a) Adequate effort should be made not only at improving the condition of service and welfare packages of the police officers but governments at all levels should endeavour to make adequate supply of modern operational equipments for intelligence gathering and security surveillance to enable them rise up to all kinds of emerging threats in the country.

(b) There is need for strategic education on the various policing, arms control/nonproliferation, and as well as bomb explosives diffusion strategies; and they should be well trained on the global best practices on community policing; community-police relations; and also the need for interagency collaborations among security agents for adequate border security in order to checkmate the influx of foreign criminals.

(c) The police and the general public are advised to immediately discard the notion of enmity and rivalry that usually exist between them for the spirit of togetherness, building a strong synergy in the course of protecting lives and property in the society.

(d) Additionally, the Nigeria Police should nurture the spirit of honesty, justice and fairness in the course of discharging their primary responsibilities in the state.

(e) Also, in the line of fortifying the bond between the police and the general public, the Nigeria Police should not only take or view their barracks and police stations as the only places of discharging their duties, but should take into cognizance the fact that their efforts can only become more effective as they maintain strong relations with the members of the public.

\section{REFERENCES}

Abdulrahaman, Y. (2007) "Preface in Community Policing" Nigeria Police Force Handbook. Abiodun, T. F. (2018). Proliferation of Small Arms and Light Weapons in the South-South Region of Nigeria and National Security. Ph.D Thesis (Unpublished), Ekiti State University, Ado-Ekiti (2018). 236pp

Abiodun, T. F. (2020). Usage of Drones or Unmanned Aerial Vehicles (UAVs) for Effective Aerial Surveillance, Mapping System and Intelligence Gathering in Combating Insecurity in Nigeria. African Journal of Social Sciences and Humanities Research (ISSN: 2689-5129), Vol. 3, Issue 2, pg. 29- 44.

Abiodun, T. F., Asaolu, A. A., and Ndubuisi, A. I. (2020). Defence Budget and Military Spending on War against Terror and Insecurity in Nigeria: Implications for State Politics, Economy, and National Security. International Journal of Advanced Academic Research. Vol. 6, Issue 7. (2488 - 9849) (Nigeria) 
Abiodun, T.F. (2016). An Appraisal of Nigeria's Counter-Terrorism Policy: The Case of Boko Haram. In Akinwumi, F.S., and Olaniyan, D.A. (Eds.) Global Perspectives in Education. Ibadan: His Lineage Publishing House. 145-155pp. ISBN 978-978-52551-40. (Nigeria)

Adekunle, T. K. (2013). Rethinking Community Policing in Nigeria. In I.O. Albert and W. A. Eselebor (eds.) Managing Security in Globalised World. Society for Peace Studies and Practice (SPSP). Ibadan: John Archers Publishers Ltd.

Adesola, O. (2021). "A Whatsapp Discuss on General Insecurity and the Call for Community Policing in Nigeria." Discuss made via Whatsapp Call on 19 March, 2021.

Akers, R. L. (1998). Social Structure and Social Learning. Los Angeles: Roxbury.

Alderson, J. (1983). "Police" in D. Walsh and A. Poole (eds.), A Dictionary of Criminology. London: Routledge and Kegan Paul.

Alemika, E. (1993) "Colonialism, State and Police Nigeria: Crimes, Law and Social Change.

Allison T. C. and Alex, R. P. (2004). "Applying social learning theory to police misconduct." Deviant Behavior, 25: 89-108, 2004. Taylor and Francis.

Alpert, G. P. and Roger, G. D. (1997). Policing Urban America. Illinois: Waveland Press.

Ayuba, M. (2019). Impact of Rural Banditry to Human Security in Northern Nigeria. M.Sc research project submitted to the Department of Political Science, Kaduna State University, Kaduna (Unpublished).

Baker, B. (2008) Multi-Choice Policing Stockholm: Elanders Gotab AB.

Bohn, R.M., Haley, K. N. (2002): Introduction to criminal Justice .New-York: McGraw Hill. Brown, J. (2001) “Community Policing Reality Check." Law and Order, April 2001, pp. 5558

Conser, James A. 1980. “A Literary Review of the Police Subculture: Its Characteristics, Impact and Policy Implications." Police Studies 2: 46-54.

Coquilhat, J. (2008), Community Policing: An International Literature Review.Wellington: New Zealand police

Cordner, G. W. (1999): "Elements of community policing in policing Perspective: an anthology, edited by Gaines, L. K. and Cordner, G. W. Los Angeles, p ox burry pub. Co.

Dambazau, A. B. (2007): Criminology and Criminal Justice. Ibadan: spectrum Book Ltd.

Donli, P. (2021). "Insecurity in the northeastern region of Nigeria since 2009." A Workshop Presented at the TETFUND National Research Fund Project on: Developing Standards for Monitoring, Assessment and Evaluation of Peace and Conflict Management Projects in Nigeria; on 18 March, 2021, at Denis Hotel, Abuja.

Federal Republic of Nigerian Constitution, (1999).

Kappeler, Victor E., Richard D. Sluder, and Geoffrey Alpert. 1998. Forces of Deviance: Understanding the Dark Side of Policing, 2nd ed. Prospect Heights, IL: Waveland Press.

McCafferty, F., S. Souryal, and M. McCafferty. 1998. "The Corruption Process of a Law Enforcement Officer: A Paradigm of Occupational Stress and Deviancy.' Journal of the American Academy of Psychiatry and Law 26:433-58.

McEwen, T. (1998) "Chicago Bold Experiment on Policing." Law Enforcement News, January 31, pp.13-14.

Miller, L.S. and Hess, K.M. (2002) The Police in the Community: Strategies for the 21st Century. 3rd ed. Belmont, CA: West/Wadsworth Publishing Company. 
Ocholi, D. (2009) "Anarchy is its other name; Security Agencies are Helpless as Kidnappers, Assassins and Robbers Reign Supreme in Virtually All Parts of the Country" Newswatch (Special Independence Edition) vol. 50 no 14 Oct.5

Okiro, M.M. (2007) "Forward in community policing" Nigeria Police Force Operational Handbook.

Osakwe, E. (2009) "Navigating the Nation through today's Shame to Tomorrow's Fame; Social Studies as a Pilot" $17^{\text {th }}$ Inaugural Lecture, Delta State University, Abraka, Benin: Justice Jecco Press and Publications Limited.

Palmiotto, M. (2000), Community Policing: A Policing Strategy for 21 st Century, Aspen Books.

Reiner, T. (2002): The politics of the police, Oxford University press.

Rotimi, K. (2001) "The Police in a Federal State, the Nigerian Experience" Ibadan: College Press Publishers Limited.

Segrave, M. and Ratcliff, J. (2004) Community Policing: A Descriptive Overview

Skogan, W. (2006) 'Advocate-The Promise of Community Policing' in Police Innovation: Contemporary Perspectives, ed. D. Weisbued and A. Braga, Cambridge University Press: Cambridge, pp. 27-43

Skogan, W. and Steiner, L. (2004) Community Policing in Chicago, Year Ten. Chicago: Illinois Toronto, pp. xvii

Skolnick, J.H. and Bayley, D.H. (1988) "Themes and Variation in Community Policing", Crime and Justice, Vol. 10. Pp1-37

Sola, T. (2021). "A Whatsapp Discuss on Police Experience During \#EndSARS Protests\#, General Insecurity and the Call for Community Policing in Nigeria." Discuss made via Whatsapp Call on 16 March, 2021.

Tamuno, T.N. (Ed) (1993) "Policing Nigeria: Past, Present and Future" Lagos: Malthouse Press Limited.

The Dawn Newspaper (2011). "Community Policing and National Security Community Policing in Nigeria" Thursday 27, January, 2011

The Protocol of Eastern African Police Chiefs Cooperation (2008).

Weber, M. (1968): Economy and society University of California press.

Wong, K. (2009) “A General Theory of Community Policing” http://works. Bepress.com/Kan Wong /6/

Wrobleski, H. M. and Hess, K. M. (2003): Introduction to Law Enforcement and Criminal Justice seventh edition. U.K. Wards worth 